\title{
Determinants of disability pensions in Croatia: the role of institutions
}

MARIJANA BAĐUN, Ph.D.*

\section{Article**}

JEL: H0

https://doi.org.10.3326/pse.41.1.10

\footnotetext{
* The author would like to thank Ljiljana Marušić (Croatian Pension Insurance Institute) for helpful comments during research and Gordana Živec Šašić (Croatian Pension Insurance Institute) for providing data. The author is also grateful to participants of roundtables organized by the Institute of Public Finance and Banka magazine within the project "Pension System Analysis" and participants of the Public Sector Economics Conference. Finally, many thanks go to the two anonymous referees for useful comments and suggestions.

${ }^{* *}$ Received: October 19, 2016
}

Accepted: December 15, 2016

A previous version of this paper was presented at the conference Public Sector Economics organized by the Institute of Public Finance and the Friedrich-Ebert-Stiftung in Zagreb on October 14-15, 2016.

\section{Marijana BAĐUN}

Institute of Public Finance, Smičiklasova 21, 10000 Zagreb, Croatia

e-mail: marijana.badjun@ijf.hr

ORCID iD: 0000-0001-9645-1540 


\section{Abstract}

The goal of this paper is to investigate why Croatia has a large number of disability pension beneficiaries. Approximately one quarter of Croatia's retired population is receiving a pension based on disability. After a presentation of the most important facts and figures, the following possible determinants of disability pensions in Croatia are considered: health status, conditions of work, socioeconomic status, war, and institutions. Simple before-after comparisons suggest that institutional reforms had a strong impact on the number of disability pension beneficiaries. Furthermore, the granting of disability pensions has been plagued by corruption, which shows the importance of informal institutions as well. Future research should focus on microdata in order to find specific social and health care policy measures to alleviate the effect of socioeconomic and health factors on the incidence of disability.

Keywords: disability pensions, Croatia, corruption, war, institutions

\section{INTRODUCTION}

It is widely acknowledged that institutions matter. "Institutions form the incentive structure of a society, and the political and economic institutions, in consequence, are the underlying determinants of economic performance" (North, 1994). They consist of formal constraints (e.g. regulations, laws, constitutions), informal constraints (e.g. norms of behaviour, self-imposed codes of conduct, conventions), and their enforcement characteristics. A pension system is framed by institutions as well, and disability pensions are no exception, even though it seems obvious that they are primarily health dependent.

Krokstad and Westin (2004) study medical and non-medical causes of disability pensions in Norway and discover that medical determinants alone cannot interpret the increased incidence rates of disability pensions in the observed two decades. They find a geographic pattern for the prevalence of disability pensions at a municipality level, which suggests that structural and cultural factors are also vital in determining the level of disability in society. A study of disability pensions among immigrants in Sweden (Österberg and Gustafsson, 2006) shows that foreign-born individuals are more likely to have a disability pension than native-born Swedes. Specifically, the highest rates of receipts of disability pensions are reported for persons born in Greece, Yugoslavia (Croatia is one of Yugoslavia's successor countries) and Turkey. The authors classify these countries as East Mediterranean. They do not investigate the causes of the higher risk of being on a disability pension. Interestingly, Börsch-Supan, Brugiavini and Croda (2009) find that the southern countries in their sample have a high prevalence of early retirees. The geographical variation highlights the possible importance of informal institutions.

Research by Börsch-Supan, Brugiavini and Croda (2009) also leads to a conclusion that health and demographics play only a small role in cross-national differences in work and retirement, even when it comes to disability benefits. Most international variation in disability-benefit recipiency rates can be explained by the insti- 
tutional factors. As institutional factors the authors employ a set of OECD (2003) variables on the generosity of the disability benefit system in each of the 11 countries covered by the Survey of Health, Ageing and Retirement in Europe (SHARE). These variables measure coverage, minimum disability level required for full benefits, medical assessment, benefit generosity, vocational assessment, and the generosity of the unemployment benefits. The most important institutional variable, which explains $60 \%$ of the cross-national variation, is the minimum level of disability required for obtaining full benefits. Health is a significant determinant of earlier retirement within each country.

Hanel (2012) also points out that disability benefits may serve as an exit route to early retirement and encourage individuals to leave the labour force early. In her study of the institutional reform of disability pensions in Germany in 2001 she finds that individuals whose health status is very bad do not react to financial incentives because a labour market income is not attainable. The opposite holds true for people who are of relatively good health. Their decision to enter disability retirement depends on the implicit tax rate on further work, i.e. the extra gain in income from further work. Research on Denmark confirms that when people experience an acute health shock, the retirement effect following it is immune to various welfare state programs and institutions available to older workers (Datta Gupta and Larsen, 2007). A link between institutions and disability is found in Austria as well. Staubly (2011) shows that stricter eligibility rules have a strong influence on disability enrolment. Screening stringency is important too; De Jong, Lindeboom and Van der Klaauw (2011) use a controlled experiment in which some regional disability insurance offices in the Netherlands were notified to screen applicants more intensively. The authors find a large decrease in disability insurance applications in regions with more stringent screening.

Apart from health status and institutions, socioeconomic status is important as well: low education, low income, receipt of social benefits and unemployment increase the risk of entering disability retirement (Gjesdal et al., 2004; Karlsson et al., 2008; Krokstad and Westin, 2004; Upmark et al., 2001). Unfavourable working conditions are another risk factor for disability pensions (Falkstedt et al., 2016; Robroek et al., 2013). Gravseth et al. (2007) show the importance of biological and social factors from childhood (maternal marital status, parental disability, birth weight below the mean, chronic childhood disease, low educational achievement) for the taking of disability pension. It is further shown that relative municipality deprivation accounts to an increase in disability pension incidence (Krokstad et al., 2004). The majority of papers on the determinants of disability pensions refer to Denmark and Norway.

One of the features of the Croatian pension system is the large number of disability pension recipients. Approximately one quarter of Croatia's retired population is receiving a disability pension. This share includes disability pensions that were by law, starting from 2015, transformed into old age pensions for beneficiaries 
older than 65. In comparison, according to the latest available Eurostat (2016a) data, in 2013 disability pensions accounted for 14\% of total pensions in the European Union (average without Belgium, Greece, Hungary and Poland due to missing data). In the same year the share of disability pension expenditure in GDP in Croatia was 3\%, while the EU average (excluding Greece and Poland) was $1 \%$. A logical explanation for the high share of people receiving disability pensions in Croatia compared to other countries would be war. However, even without the war veterans, the share of disability pensions in total pensions in Croatia is approximately five percentage points higher than the EU average.

All previously mentioned papers take into account only formal institutions. To the author's knowledge, the link between informal institutions and disability pensions has not yet been studied. Since disability can only be observed imperfectly, it is difficult to determine whether claimants for disability pensions are truly disabled. The screening procedure should limit potential moral hazard, since claimants for disability pension may overstate their health problems. However, one important factor is neglected in the literature: corruption. Individuals seeking disability benefits may bribe those people who are in charge of approving applications for disability pensions.

The aim of this paper is to provide descriptive evidence of how various factors, especially institutions, affect disability pensions in Croatia. The paper is structured as follows. Section 2 describes disability pensions in Croatia through basic facts and figures. In section 3 the link between institutions, both formal and informal, and disability pensions in Croatia is analysed. Other possible factors determining the probability of someone having a disability pension are also investigated. Section 4 is the conclusion. Simple before-after comparisons suggest that institutional reforms had strong effects on the number of disability pension beneficiaries.

\section{DISABILITY PENSIONS IN CROATIA: FACTS AND FIGURES}

The leading trend in the Croatian pension system is the worsening ratio of workers/contributors to pensioners/beneficiaries. According to Croatian Pension Insurance Institute data (HZMO, 2016a), at the end of 2015 the ratio was 1.15 while in 1990 it was 3. Croatia has 1.2 million pension beneficiaries, which is $28 \%$ of the total population. The average net pension is ca HRK 2,400 (EUR 320) and the share of pension expenditures in GDP is about $11 \%$. Only $55 \%$ of pension expenditures are covered by the pension insurance contributions of the currently employed, while the remaining $45 \%$ comes from the government budget. The mandatory retirement age for men is 65 and for women 61.5 but it is gradually being increased until 2030, when it will be 65 too. However, approximately one fifth of old-age pension beneficiaries entered early retirement.

One pathway to early retirement inheres in obtaining a disability pension. At the end of 2015 around 207,300 people in Croatia were receiving disability pensions, but this number excludes approximately 87,200 beneficiaries of disability pen- 
sions that were by law at the age of 65 transformed into old age pensions starting from 2015 (HZMO, 2016b). Altogether, there were around 294,500 beneficiaries of pensions based on disability. The majority of them obtained their pension by the general Pension Insurance Act - ZOMO (75\%), and the second largest group consists of Croatian Homeland War veterans, i.e. Croatian defenders (20\%), followed by members of the Croatian Army (3\%) and members of the Croatian Defence Council - HVO (2\%). For the last three groups special laws apply, the most important one being the Law on the Rights of Croatian Defenders from the Homeland War and of Members of Their Families - ZOPHBDR. In the total number of pension beneficiaries, disability pension recipients comprised $18 \%$, or $24 \%$ when the disability pensions of the previously mentioned three groups are added to the beneficiaries of disability pensions under ZOMO.

Figure 1 shows the trend in the number of beneficiaries of disability pensions from 1995 to 2015. The greatest rise occurred in 1999, because the new Pension Insurance Act was passed. On this occasion the previous work-disabled recipients of disability-related benefits, were transformed into recipients of disability pensions. Since that time, the number of beneficiaries of disability pensions defined according to $\mathrm{ZOMO}$ has been relatively stable, with the proviso that this number rose by $8 \%$ from 2005 to 2010. In addition, starting from 2010 the number of disability pension beneficiaries has started falling. The sharpest drop happened from 2014 to $2015(41 \%)$ due to the already mentioned transformation of disability pensions into old-age pensions at the age of 65 if the underlying cause of disability was a disease. ${ }^{1}$ Other possible factors are injury, occupational disease and accident at work. Furthermore, a Single Body of Expertise started working in 2015, which means that the Croatian Pension Insurance Institute (HZMO) is no longer charged with making decisions on medical eligibility for a disability pension.

The number of beneficiaries of the HRVI (Croatian wartime military disabled) status, that is, defenders', or veterans', disability pensions in terms of ZOPHBDR rose almost three times in the period from 2003 to $2012 .^{2}$ The data before 2003 are not available. The greatest rise was recorded in 2007, for then 5,500 defenders who had received benefits for incapacity to work were transformed into recipients of disability pensions. Since 2012 the number has been falling.

\footnotetext{
${ }^{1}$ Transformation of disability pensions into old-age pensions is not uncommon. This is also the case in, for example, the Czech Republic, Finland, Latvia, Poland, Spain and Sweden.

${ }^{2}$ According to this Law, a Croatian wartime military disabled person from the Homeland War is defined as a Croatian defender whose organism is at least $20 \%$ impaired because of a wound or injury obtained defending the sovereignty of the Republic of Croatia, or as a prisoner in prison or enemy camp. It is considered that the impairment of the organism of a captive in an enemy camp is at least $20 \%$ permanent. A HRVI (Croatian wartime military disabled) is a Croatian defender whose organism is at least $20 \%$ impaired because of illness, and the illness, or deterioration of the illness or the occurrence of the illness is an immediate consequence of involvement in the defence of the sovereignty of the Republic of Croatia in the Homeland War. HRVI rights can also be claimed by a person (medical personnel, war reporters, members of fire-fighting units, sailors, crew members of ships of the merchant marine and other persons) whose organism is at least $20 \%$ impaired because of a wound or injury obtained in the performance of military or other duties at the order of the competent bodies of government of the Republic of Croatia in the defence of the sovereignty of the Republic of Croatia in the Homeland War or as a captive in an enemy camp in the Homeland War.
} 


\section{Figure 1}

Disability pension beneficiaries (in thousands)

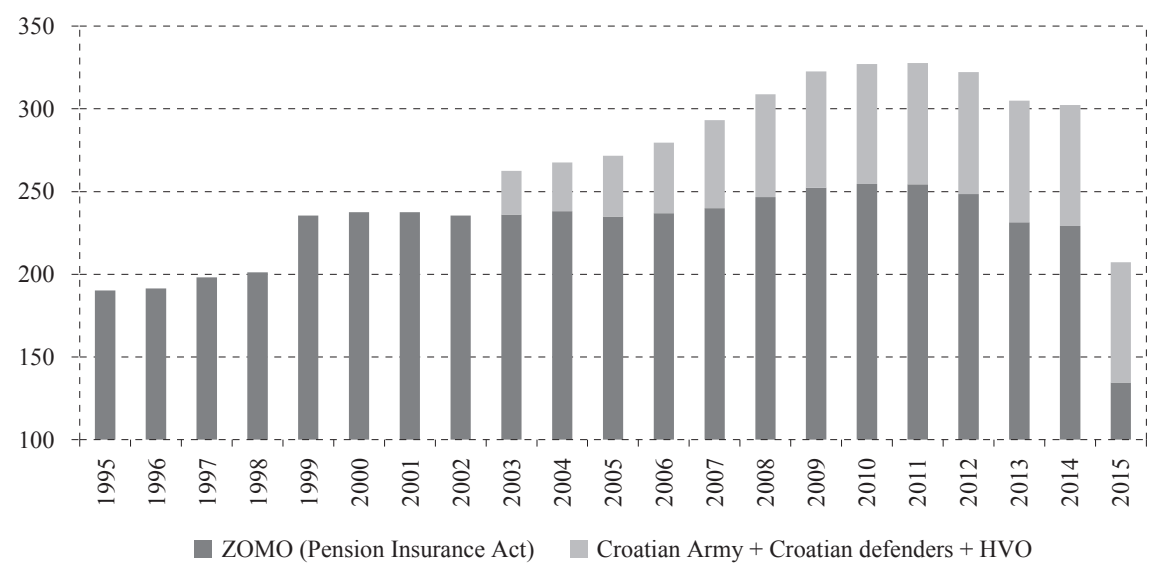

Note: In HZMO publications data for the Croatian Army and defenders before 2003 are not available, and HVO pensions have been awarded since 2008.

Source: $H Z M O$.

From a look at the trends of just the new beneficiaries of disability pensions according to ZOMO (figure 2), still more obvious is the sudden rise in 1999 of 37,112 new beneficiaries, which was $45 \%$ of total new beneficiaries in that year. Also salient is 1995 , because of the war, and quite large rises are also perceptible in 1998, 2008 and 2009. During the economic crisis the number of new beneficiaries of disability pensions has been falling, but the number of beneficiaries of early retirement pensions has been increasing (figure 3). Determinants of early retirement should be separately analysed (see Vukorepa (2015) for legal changes) but entering early retirement has often been a way to find financial security within the pension system for people who are unemployed or have a high risk of becoming unemployed.

\section{Figure 2}

New beneficiaries of disability pensions according to the Pension Insurance Act - ZOMO (in thousands)

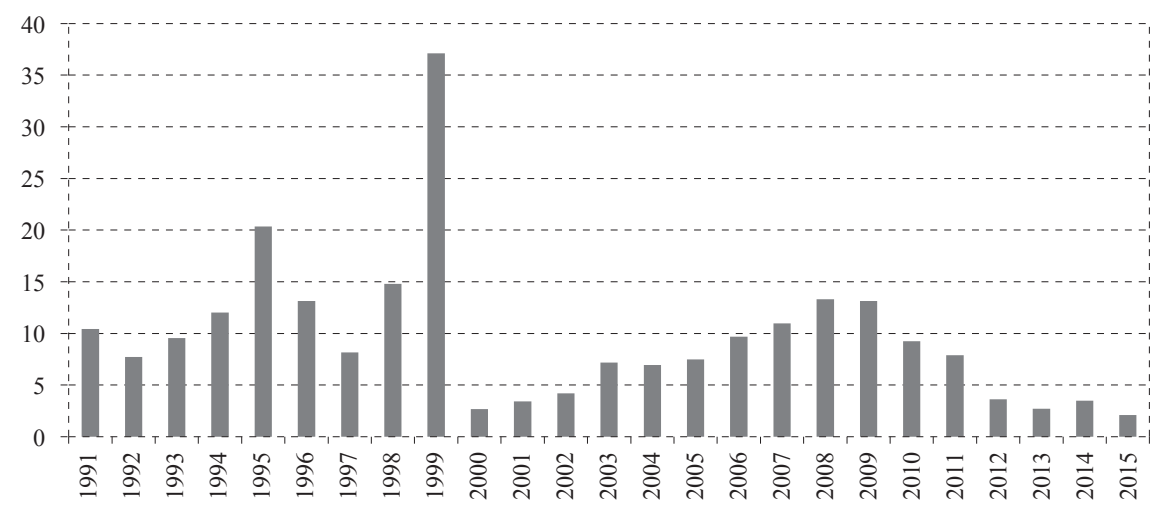

Source: $H Z M O$. 
Figure 3 shows the proportions of individual categories in the total number of pensions beneficiaries according to ZOMO (these figures do not include the Croatian Army, the HVO and defenders in terms of ZOPHBDR). The proportion of survivors' and disability pensions has not changed considerably over the course of time (except in 2015), but a rise in the proportion of early retirement pensions is observable: in 2000 there were $3 \%$ of them, in 2015 as many as $15 \%$. At the end of 2015 , along with $15 \%$ of early retirement pensions, there were $53 \%$ of old age pensions, $12 \%$ of disability pensions and $20 \%$ of survivors' pensions (HZMO, 2016b). Although the law discourages early retirement, it is still on the rise.

\section{Figure 3}

Proportions of individual categories in the total number of pensions beneficiaries according to the Pension Insurance Act - ZOMO (in \%)

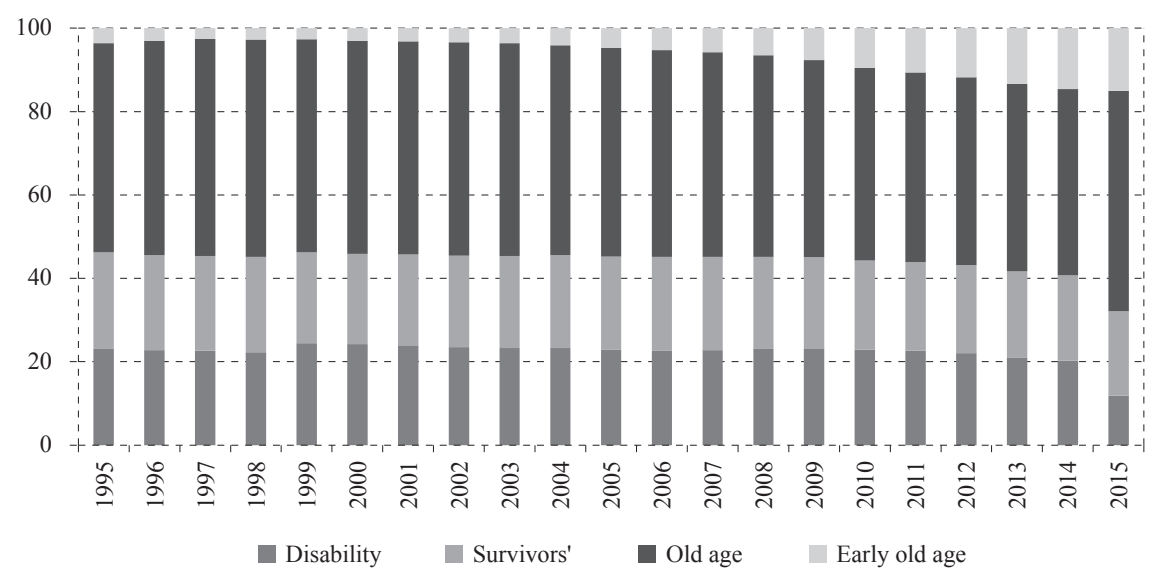

Source: HZMO, author's calculations.

According to ZOMO, a disability pension can be obtained if an insured person has one of two possible types of disability: occupational or general incapacity for work, in addition to completed qualifying period. The former is considered to be total disability and the latter partial. Temporary disability pension has also been introduced in 2015 for persons with reduced working capacity who even after having completed professional rehabilitation remained unemployed for at least 5 years, provided that their unemployment lasted until the age of 58 (Vukorepa, 2015). At the end of $2015,43 \%$ beneficiaries had total disability, and at the end of $201466 \%$. Obviously, total disability was more prevalent among beneficiaries whose disability pensions were at the age of 65 transformed into old-age pensions in 2015 . At the end of 2015 a total disability pension was approximately HRK 300 higher than a partial disability pension.

Beneficiaries of disability pensions have particular characteristics as compared with other pension beneficiaries, and they also differ within the group. The average age of old age pension beneficiaries according to ZOMO in 2014 was 71 years, while that of holders of disability pensions was 64 years (HZMO, 2015). 
Disability pension beneficiaries take pensions earlier than beneficiaries of old age pensions: the average age for the former at retirement is 53 years, for the latter 62 (data for new beneficiaries in 2015). They also have a shorter contributions record: 23 years as compared with 34 years. Still, in spite of retiring earlier, disability pension beneficiaries on average use their pensions only a year longer ( 20.5 years) than old age pensioners (19.5 years) - data for beneficiaries who died in 2014. From this it can be concluded that the health problems of beneficiaries of disability pensions considerably shorten their life spans.

The next feature is the average amount of pensions. The average disability pension paid out in December 2015 for beneficiaries according to ZOMO came to HRK 1,842, while the old age pension came to HRK 2,413 (HZMO, 2016b). However, beneficiaries of disability pensions who acquired the right to a pension up to 1999 had an average pension of HRK 2,378, while beneficiaries who achieved that status after 1999 got HRK 1,742. Here only "true" disability pensions were taken into account, and not those that were transformed into old-age, but the amounts are similar. The average HRVI (defender) pension came to HRK $4,850 .{ }^{3}$

Unfortunately, the Croatian Pension Insurance Institute (HZMO) does not publish records of beneficiaries of disability pensions according to groups of disabilities. In the EU, the structure is as follows (Marušić, 2011): mental disability (27.6\%); skeleto-muscular disabilities (21.7\%); vascular diseases $(11.8 \%)$; neoplasms (10.5\%); congenital disabilities $(0.8 \%)$; and other disabilities $(27.6 \%)$. However, the Croatian Institute for Public Health (HZJZ) does publish the most common diagnoses for the causes of the disabilities of persons claiming disability rights via the HZMO. Apart from disability pension, disability rights are also: compensation for physical impairment, which results from work injury or professional disease (71,710 beneficiaries at the end of 2015 according to HZMO), and assistance and care allowance (7,919 beneficiaries). Starting from 1999 the latter right has been transferred from the domain of pension insurance to that of social welfare. In April 2016, 313,847 persons claimed disability rights via HZMO, a number that does not include defenders (HZJZ, 2016a). HZJZ obtains information about defenders from the Ministry of Veterans' Affairs.

Table 1 can lead to the conclusion - after all forms of mental sickness and disorders are aggregated - that the structure of beneficiaries of disability pensions per disability group is similar to that of beneficiaries of disability pensions in the EU. Mental illnesses and disorders dominate; after that come skeleto-muscular illnesses and disorders of the vascular system. HZJZ also keeps records of the most common causes of physical impairments to persons who claim disability rights via HZMO, but the percentage of physical impairments had been determined for

\footnotetext{
${ }^{3}$ People in the HRVI category claim their disability pensions according to ZOPHBDR. In the calculation of their pension, the general pension formula is used, but the points used depend on the basis for rank and establishment post, a special initial factor is stipulated, and personal points are enlarged by $45 \%$, while a contributions record of 40 years is assumed.
} 
around $40 \%$ persons. Dominant is "total loss of one segment of the cervical region after fracture of the spine", then "total loss of function of one segment of the lumbar region" and "limited mobility of the hip joint". Of all the persons who claimed disability rights via HZMO in April 2016, 49\% were in the active working period, $59 \%$ of them men, and $41 \%$ women.

\section{TABLE 1}

Most common diagnoses of the causes of disability of persons who claim their disability rights via HZMO in 2016

Diagnoses Number of persons

\begin{tabular}{llc}
\hline Skeleto-muscular disorders & 57,594 \\
\hline Affective disorders* & 22,899 \\
\hline Neurotic, stress-related and somatoform disorders & 20,209 \\
\hline Hypertensive diseases & 13,977 \\
\hline Arthropathies & 13,287 \\
\hline Schizophrenia, schizotypal and delusional disorders* & 8,337 \\
\hline Cerebrovascular diseases & 7,329 \\
\hline Organic mental disorders* & 6,870 \\
\hline Diabetes mellitus & 6,240 \\
\hline Mental disorders due to use of psychoactive substances & 5,095 \\
\hline
\end{tabular}

*Mental illnesses and disorders.

Source: HZJZ (2016a).

\section{Figure 4}

Share of people receiving disability pensions in total population by counties (\%, in 2014)

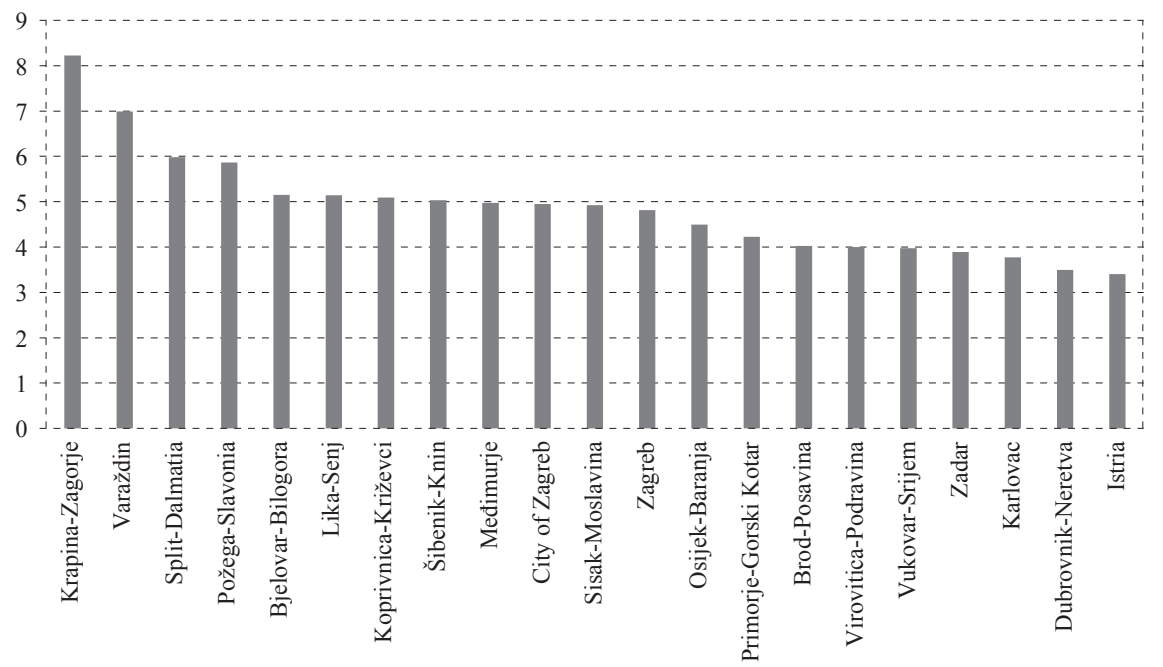

Source: HZMO and author's calculations.

The highest share of disability pension beneficiaries in the total population at the end of 2014 (HZMO, 2015) was recorded in Krapina-Zagorje County (8.2\%), fol- 
lowed by Varaždin County (7\%) and Split-Dalmatia County (6\%). The lowest share was in Istria County (3.4\%) and Dubrovnik County (3.5\%). The ranking is very similar when the share of disability pensions in total pensions is taken into account. There is no clear Continental/Adriatic pattern due to Split-Dalmatia County having one of the highest shares of disability pensions and at the same time Karlovac County one of the lowest. The difference among counties should be further examined.

\section{DETERMINANTS OF DISABILITY PENSIONS IN CROATIA}

The choice of factors that affect the number of beneficiaries of disability pensions in this paper is partially related to earlier scientific research (mainly from Scandinavian countries) in which the emphasis is placed on health indicators, working conditions and socio-economic status. The other two factors (war and institutions) were arrived at from a study of data for Croatia, that is, from its specific features.

\subsection{HEALTH INDICATORS}

As mentioned in the Introduction, persons who suffer from chronic diseases and who are in general in a poor state of health have a greater likelihood of becoming beneficiaries of disability pensions. Accordingly, here certain health indicators and risk factors are adduced. At the beginning, it is the most important to bring out the expectancy of healthy years of life at birth. The average for the EU15 in 2015 came to 71.8 years, and for Croatia 69.4, which is three years longer since 2000 for Croatia (WHO, 2016). However, the difference between the EU28 and Croatia in healthy life years at ages 50 and 65 is approximately three years (Eurostat, 2016b). Furthermore, in 2010, only $48 \%$ of people in Croatia were self-assessed as being in good or very good health (Eurostat, 2016b). This is the worst result among EU countries, alongside Latvia. In Scandinavian countries, for example, this number is above $70 \%$. However, self-assessed health in Croatia seems to be improving; in 2014, 58\% of people in Croatia were self-assessed as being in good or very good health, while the EU28 average was $67 \%$.

It was said earlier that among users of disability rights, cardiac patients represent a high percentage. In Croatia in 2013, the age-standardised mortality rate for all ages per 100,000 inhabitants for ischaemic heart conditions came to 188 for men and 114 for women. In the EU15 the average for men was 78, and for women 36 (WHO, 2016). As for the issue of mortality rate for mental disorders and disorders of the nervous system, the value for Croatia in 2013 was 29 and in EU15 countries 41. The age-standardised mortality rate for all ages per 100,000 inhabitants for malignant neoplasms in 2013 in Croatia was 210 (the second worst result after Hungary) and in EU15 countries 156 . Improvement can be reached both by appropriate care for one's own health and by preventive examinations. According to 2014 figures, in Croatia 59\% of the population over the age of 18 was overweight, which is the same as EU15 average. In addition, $27.5 \%$ of the population over 15 were smokers, and in the EU15 22\%. Croatia had a greater average annual consumption of pure alcohol per capita: 12 litres as against 10 litres in the EU15. 
Since 2002, HZJZ has kept a Croatian Disabilities Registry, but the first data only became available for 2009, because of the time needed to organise the Registry and collect data. ${ }^{4}$ In April 2016 there were 511,121 persons in the Registry, 60\% of them men and 40\% women (HZJZ, 2016a). According to this, the prevalence of disability in the Republic of Croatia amounts to $11.9 \%$. Table 2 shows data from the Registry according to kind of impairment. Among persons with disabilities, impairments of the locomotor system and multiple impairments dominate, followed by mental disorders and impairment of other organs.

\section{TABLE 2}

Presentation of the kinds of impairment that lead to disability or as comorbidity diagnoses contribute to the degree of functional impairment of the organism (2015)

\begin{tabular}{|c|c|c|}
\hline Kinds of impairment & $\begin{array}{c}\% \text { of total } \\
\text { disabled persons }\end{array}$ & $\begin{array}{c}\text { Prevalence/ } \\
10,000 \text { inhabitants }\end{array}$ \\
\hline Impairment of the locomotor system & 29.5 & 351 \\
\hline Mental disorders & 25.2 & 301 \\
\hline Impairment of other organs & 23.1 & 275 \\
\hline Impairment of the central nervous system & 18.2 & 217 \\
\hline Intellectual difficulties & 4.8 & 57 \\
\hline Learning disabilities & 4.4 & 53 \\
\hline Impairment of sight & 3.4 & 41 \\
\hline Impairment of hearing & 2.6 & 31 \\
\hline Impairment of the peripheral nervous system & 2.4 & 29 \\
\hline Congenital anomalies and chromosopathies & 2 & 24 \\
\hline Pervasive developmental disorders & 0.4 & 4 \\
\hline Multiple impairments & 29.5 & 352 \\
\hline
\end{tabular}

*Overall number of diagnoses exceeds the number of disabled persons due to multiple impairments. Source: HZJZ (2016a).

\subsection{CONDITIONS OF WORK AND SOCIO-ECONOMIC STATUS}

Conditions of work also affect the likelihood that someone will become a beneficiary of a disability pension. As can be seen from figure 5 , the sharpest fall in the number of accidents was recorded from 1990 to 1992, and again from 2008 to 2014, as a result of an economic downturn (Bađun, 2016). The largest number of accidents $(44,900)$ was reported in 1990 and the smallest in $2014(13,785)$. In 2015, there were 16,015 accidents at work (HZJZ, 2016a).

The 2014 EU average was 1,536 accidents (excluding fatal accidents) per 100,000 persons employed (Eurostat, 2016c). Croatia performed better than the EU average, with 870 accidents per 100,000 persons employed. Worth noting are some statistical problems concerning accidents at work, such as: (1) under-reporting; (2) questionable accuracy of data on the number of employed persons by activity

\footnotetext{
${ }^{4}$ According to the Law concerning the Croatian Disabilities Registry, disability is a permanent limitation, reduction or loss of capacity (deriving from impaired health) to perform some physical activity or psychic function appropriate to the age of the person and that relates to capacities, in the form of complex activities and conduct universally accepted as essential components of everyday life.
} 
(which influences the incidence rate of accidents); and (3) differences across countries in the definition of persons subject to reporting obligation (Bađun, 2016). The problem under (1) arises from either employers' ignorance or their fear of the financial damage for the company due to higher needs for investment in safety at work. An additional problem is "the black economy". In 2014, fatal accidents at work in the EU totalled 3,739. Croatia reported 1.9 fatal accidents at work per 100,000 persons employed (the EU average was 1.8). Fatal accidents are almost always reported, which explains the more consistent statistics. It is interesting to point out that only $3.8 \%$ of disability pension beneficiaries in Croatia receive their pension on the basis of work injury or professional disease (data for March 2016 provided by HZMO upon an Access to Information Request).

\section{Figure 5}

Accidents at work (in thousands) and incidence rate of accidents at work per 100,000 active insured persons in Croatia (in thousands)

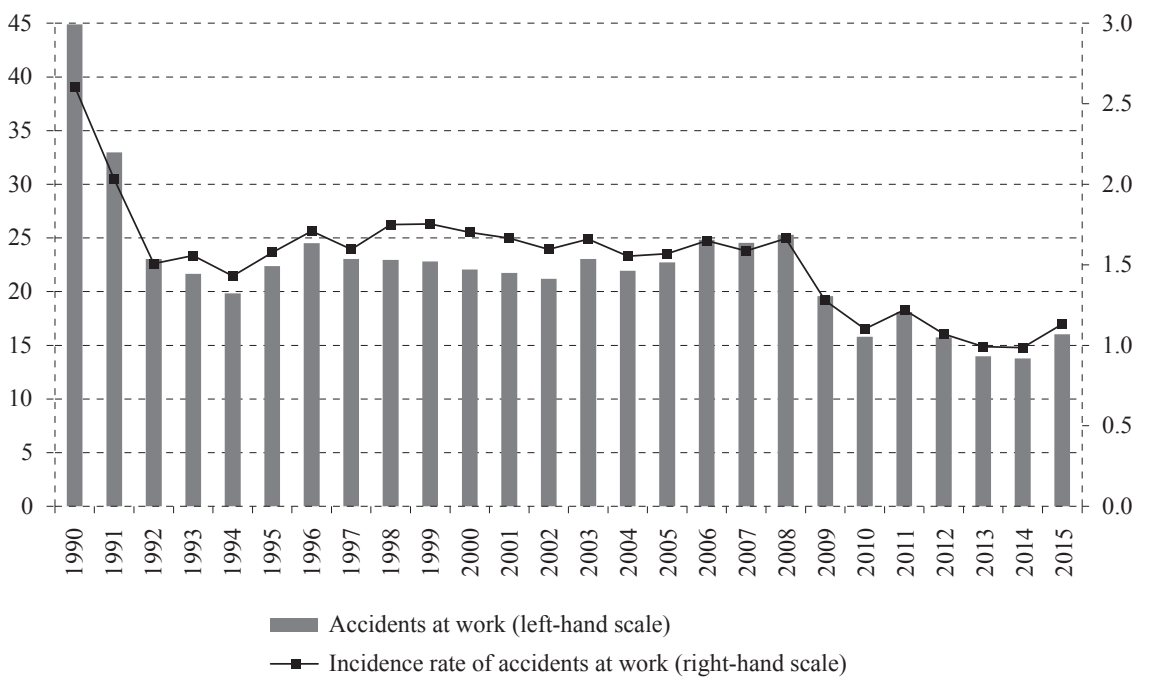

Source: HZJZ.

Persons with lower education are more probable beneficiaries of disability pensions. According to data from the Croatian Disabilities Registry for March 2016, $63 \%$ of persons with disability have elementary level education or less, $28 \%$ have secondary qualifications and only $3 \%$ have tertiary qualifications (HZJZ, 2016b). Croatia has in general a lower standard of education; according to the census of $2011,31 \%$ of the population older than 15 are educated only to elementary level, or have less than complete elementary education, or no education at all (DZS, 2011). Unfortunately, data on the education structure of disability pensioners are not available. Unemployment also has an influence on the greater likelihood of taking up disability pensions, and unemployment is one of the greatest economic problems in Croatia. In 2015 the unemployment rate was 16.3\% (HNB, 2016). 


\subsection{WAR}

Both World War II and the Homeland War increased the number of beneficiaries of disability pensions in Croatia. In the Croatian Disabilities Registry at the end of 2015 there were 60,053 veterans with disabilities, of whom 57,566 were receiving pensions (HZJZ, 2016a). Eighty-seven per cent of HRVI pensioners receive disability pensions because of general incapacity to work. The Registry has data about the most frequent diagnoses of veterans with disabilities, but not about the numerical structure of veterans per diagnosis. The five most frequent diagnoses are: (a) post-traumatic stress disorder (PTSD) as a result of captivity or trauma of war, (b) major muscular injuries with functional handicaps, (c) clinically established neuroses and psychoses, (d) impairment of nerves in the lower extremities, (e) disc hernia after trauma (HZJZ, 2016a).

However, data are available about veterans with disabilities in terms of percentage impairment to the organism (table 3 ). About $80 \%$ of veterans with disabilities have $20-40 \%$ impairments of the organism, and $1.4 \%$ of them have $100 \%$ impairment. To be precise, 851 HRVI veterans have $100 \%$ impairment, the most common causes of disability being: fractured spinal column, amputation of one or both legs above the knee, serious impairment of the sight, amputation of one or both legs below the knee and the results of damage to the nerves of the lower extremities.

Table 3 shows a comparison of veterans with disability and beneficiaries of invalidity benefits via HMZO in terms of percentage of impairment of the organism. While in the case of veterans there are most beneficiaries with $20 \%$ impairment, in the case of beneficiaries of disability rights via HZMO those with $70 \%$ impairment dominate. According to the Regulations for the Determination of the Percentage of Impairment of the Organism of HRVI veterans of the Homeland War, PTSD represented less than 20 , or 20 or 30 or $40 \%$ impairment, and it can be assumed that a large share of the veterans with disabilities have "only" PTSD or PTSD with an additional diagnosis that represents a relatively small impairment of the organism. According to a Croatian government report (Vlada RH, 2014:38), PTSD is the leading cause of disability among HRVI veterans. About $56 \%$ of HRVI pensions beneficiaries are between 40 and 55 years old, while for beneficiaries of disability pensions according to ZOMO, the age structure is not published. The average contributions record period of HRVI veterans in 2015 was 20 years and 5 months, while in the case of ZOMO-classified disability pensions beneficiaries (including those that were transformed into old-age pensions), it is 3 years longer (HZMO, 2016b).

In spite of the longer contributions record and the average greater degree of impairment of the organism, in the case of beneficiaries of disability pensions according to ZOMO, their average pension is about 2.5 times smaller than a HRVI pension. Here one should once again remark that - unfortunately - no data about the physical impairment of the beneficiaries of disability pensions exist, rather of disability rights, but most claimants actually receive a pension. It is also important to add 
that the percentage of physical impairment is set for only around $40 \%$ of the persons who claim their disability rights via HZMO, while in the case of veterans with disability the percentage of physical impairment is determined for all.

\section{TABLE 3}

Percentage of impairment of the organism in defenders with disabilities and claimants of disability rights via the HZMO

\begin{tabular}{|c|c|c|}
\hline $\begin{array}{c}\text { Organism impairment } \\
\text { percentage } \\
(\%)\end{array}$ & $\begin{array}{l}\text { Proportion of total number } \\
\text { of veterans with disabilities } \\
(\%)\end{array}$ & $\begin{array}{c}\text { Proportion of beneficiaries } \\
\text { who claim disability rights } \\
\text { via HZMO (in \%) }\end{array}$ \\
\hline 100 & 1.4 & 8.9 \\
\hline 90 & 0.7 & 0.4 \\
\hline 80 & 1.5 & 0.7 \\
\hline 70 & 2.5 & 37.1 \\
\hline 60 & 4.6 & 2.8 \\
\hline 50 & 7.8 & 5.1 \\
\hline 40 & 17.4 & 15.3 \\
\hline 30 & 25.3 & 29.7 \\
\hline 20 & 38.8 & 0.0 \\
\hline Total & 100.0 & 100.0 \\
\hline
\end{tabular}

${ }^{a}$ Percentage of physical impairment is established for about $40 \%$ of the persons who claim disability rights via HZMO (exclusive of veterans).

Source: HZJZ (2016a).

In April 2016 Croatia also had 7,684 disabled veterans of World War II and civilian disabled of the war and post-war period (HZJZ, 2016a). Around 55\% of them are older than 75 , with the proviso that most persons have an impairment rated at $60 \%$, and there is about the same percentage of persons with $30 \%$ impairment. The most frequent diagnoses are: major muscle injury, impairment of sight, head and neck deformities, and scarring that disturbs organ function. It is undisputed that war affects civilians, not only soldiers, but HZMO does not keep records about civilian disabled in terms of disability pensions. The Croatian Bureau of Statistics publishes expenditures on rights of civilian war invalids and members of their family, but pensions are not included. In 2014 disability rights (for personal disability benefit, orthopaedic supplement, supplement for assistance and care of another person, supplement for home help) amounted to HRK 20.7 mil (DZS, 2016). Data on number of beneficiaries are not published.

According to Žilić (2015), during the war in Croatia 1991-1995 more than half a million individuals of all ethnicities were displaced. Forced displacement had adverse effects on self-assessed health, on the probability of suffering from systolic and diastolic hypertension, and on mental health. However, displacement did not cause a change in healthy behaviours; the negative effect of displacement is channelled through unfavourable economic conditions that the displaced individuals face. 


\subsection{INSTITUTIONS}

The statutory arrangement and implementation of retirement insurance also has a great effect on the number of pension beneficiaries, and also on the differences in outlays on disability pensions among countries (Marušić, 2011). In concrete terms, countries can have: (a) different definitions of disability and conditions for claiming rights; (b) a differently defined minimum degree of reduced working capacity that provides the right to a disability pension; (c) different arrangements for obtaining expert medical opinions; (d) differences in vocational rehabilitation; (e) different pensions formulae; (f) differences in whether pensions are provided only for those insured in the pensions system or to other groups as well, and so on.

Analysing institutional variations in disability pensions among different countries is beyond the scope of this paper. Regarding formal institutions in Croatia, here we shall recall the sudden jump in the number of disability pensions according to ZOMO in 1999, the increase in the number of HRVI pensions in 2007, and the decrease in the number of disability pensions according to ZOMO in 2015. In all cases, changes in regulations were involved. These changes were of an administrative nature, i.e. mostly did not change the "motivation" to enter into disability pension, but rather created a statistical mess. However, definitions of disability were also changed in 1999 and 2015 (Rismondo, 2000; Vukorepa, 2015). Regarding the transformation of disability pensions into old-age pensions, it is problematic that "old age pensions are calculated on the actual years of service (contributions paid) while disability pensions are calculated on the years of service plus 'additional period', that is a fictive period (not covered with contributions) accredited with the purpose of increasing the disability benefits" (Vukorepa, 2015:294) and now they are grouped together. This change applies only to beneficiaries according to $\mathrm{ZOMO}$, and not special regulations.

Screening stringency has been increased in order to reduce the costs of disability pensions, which resulted in a smaller number of new beneficiaries starting from 2010 (MSPM, 2014:25). Ad hoc control examinations have been introduced and recertification of disability pensions is done automatically every 3 years (it used to be 4), as prescribed by ZOMO, which came into effect in 2015. Furthermore, the Single Body of Expertise was established in 2015 to reduce fraud by unifying disability assessments. Every positive assessment is subject to review carried out by a special unit in the Ministry of Labour and Pension System. Two-step assessment was actually established in 2013 but prior to the Single Body of Expertise, the first assessment was done in HZMO. In 2015 the Strategy for Suppressing Errors, Misuse and Corruption in the Field of Social Protection in the Republic of Croatia was adopted (MSPM, 2015). According to this document, the Independent Review Sector (unit in the Ministry of Labour and Pension System) declined 27\% requests for disability pension approved by HZMO in 2013 and 23\% in 2014. In addition, the Independent Review Sector checked almost 1,000 earlier disability rights based on anonymous/non-anonymous reports. In $40 \%$ of almost 600 cases relating to physical impairment, pension rights have been reduced or abolished. 
In 2015 Croatia was one of the worst performing EU countries according to the Corruption Perceptions Index (Transparency International, 2015). In addition, Croatia's rank on the Social Capital sub-index from the Legatum Prosperity Index for 2015 (Legatum Institute, 2015) was 121 out of 142 countries, which positioned Croatia in the group with mostly African countries. The Social Capital sub-index measures countries' performance in two areas: social cohesion and engagement, and community and family networks. There is a great deal of talk about corruption in the case of disability pensions, but not enough in the way of evidence (especially for the 1990s).

Pursuant to USKOK's (State Prosecutor's Office for the Suppression of Organized Crime and Corruption) actions Diagnosis I in Split and Diagnosis II in Osijek in 2008 and 2009, 18 persons were indicted (USKOK, 2011). In both cases it was the illegal acquisition of HRVI status that was concerned. In Split bribes from EUR 4,200 to 6,500 were paid; most were taken by HZMO expert physicians and by expert physicians in the Commission for the Review of Disability Rating in the Ministry of Defenders of the Republic of Croatia. In Osijek, bribes amounted to from 5,000 to 8,000 euro, and the damage to the budget was estimated at HRK 3.2 million. The court proceedings have not yet ended, and some of the accused have died in the meantime. The largest corruption scandal regarding disability pensions came in 2012, when 69 persons were charged with taking and giving bribes in order to obtain disability pensions. The main accused was head of the medical expertise department in HZMO who immediately pled guilty and got a two-year prison sentence. ${ }^{5}$ An additional 58 of the accused reached a plea bargain with the prosecution, while the remaining 10 of them went to court. All of them were convicted in 2015; some got prison sentences and some probation (mostly people who were giving bribes).

As was previously mentioned, PTSD is the dominant disability of Croatian war veterans. Since most PTSD diagnostic elements are based on self-report, malingering is not difficult. Anecdotal case reports and medical research have shown individuals falsifying their engagement in combat and other traumas with the aim of getting benefits or financial compensation (Hall and Hall, 2006). It is a challenge for health care professionals to identify individuals with true PTSD and differentiate them from those who are only malingering. At the same time, there is fertile ground for corruption. In a paper which aimed to explain why Iraq and Afghanistan War veterans are seeking PTSD disability compensation at extraordinary rates, malingering was detected as one of the most plausible explanations (McNally and Frueh, 2013). The second very important reason was financial need, especially among veterans whose inadequate vocational skills reduces their ability to make a good living (Angrist, Chen and Frandsen, 2010).

Regulations (i.e. ZOPHBDR) determine the way in which pensions are calculated in the case of HRVI veterans. The amount of a pension certainly motivated veterans ${ }^{5}$ Alongside, he had to give government EUR 79,000 in cash and one of his apartments worth around EUR
200,000 . He got out of prison after 1.5 years. 
who could meet the conditions for a disability pension to seek pensioning and in this way settle their need to make a living without remaining in the labour market - if the physical impairment was relatively small. Campolieti (2002) has found that the increased generosity of disability benefits in the Canada/Quebec pension plan was to a great extent responsible for the increase in the incidence of musculoskeletal conditions on the disability rolls, which she considers hard-to-diagnose medical conditions. In addition, the increased rigour of medical screening has led to a reduction in the incidence of musculoskeletal conditions on the disability rolls. It is interesting to note that of almost 600,000 veterans in the USA receiving compensation for disability at the end of $2012,7 \%$ of them were receiving it for PTSD. The exact percentage for Croatia is not available, but it can be assumed that it is larger due to PTSD being the dominant diagnosis (in the USA it takes the third place).

\section{CONCLUSION AND POLICY RECOMMENDATIONS}

The pensions system is in a sense a mirror image of Croatia, which is particularly well seen in the case of disability pensions. To be more precise, most of the leading problems faced by the country are reflected in the pensions system. The ill-considered legislative framework, the consequences of the war, the poor educational structure, the high unemployment, poor conditions of work, inequality of rights, the relatively poor state of health of the general population and individuals' lack of care for their own health as well as widespread corruption have led to a large number of beneficiaries of disability pensions. From the analysis of the problem, certain recommendations for policy makers can be made: (a) better consideration of changes to the legislation, for it is hard to make up for errors after the event; (b) improvement of conditions of work and health status, particularly of individuals' care for their own health; (c) improvement of the educational structure and reduction of unemployment; (d) more emphasis on rehabilitation programs; (e) suppression of corruption; (f) equalisation of rights deriving from disability. Finally, databases should be improved, this primarily relating to records of beneficiaries of disability pensions according to groups of diseases.

It will take time to see the final results of the positive legal changes such as improvement in the medical screening procedure, stricter assessment of disability, and more frequent assessment of current health status. However, it seems that the institutional changes are already working since the leading pathway to earlier retirement is now early old-age pension. Future research should focus on microdata (e.g. SHARE data which will soon be available for Croatia) in order to find specific social and health care policy measures to alleviate the effect of socioeconomic and health factors on the incidence of disability. Health is already an important determinant of disability pensions, but after the institutional framework is "put in order", health should play an even larger role.

\section{Disclosure statement}

No potential conflict of interest was reported by the author. 


\section{REFERENCES}

1. Angrist, J. D., Chen, S. H. and Frandsen, B. R., 2010. Did Vietnam veterans get sicker in the 1990s? The complicated effects of military service on selfreported health. Journal of Public Economics, 94(11-12), pp. 824-837. doi: 10.1016/j.jpubeco.2010.06.001

2. Bađun, M., 2016. The contribution for occupational health protection. Newsletter, No. 106, pp. 1-13. doi: 10.3326/nle.2016.106

3. Börsch-Supan, A., Brugiavini, A. and Croda, E., 2009. The role of institutions and health in European patterns of work and retirement. Journal of European Social Policy, 19(4), pp. 341-358. doi: 10.1177/1350506809341515

4. Campolieti, M., 2002. Moral hazard and disability insurance: On the incidence of hard-to-diagnose medical conditions in the Canada/Quebec Pension Plan disability program. Canadian Public Policy, 28(3), pp. 419-442. doi: 10.2307/3552230

5. Datta Gupta, N. and Larsen, M. 2007. Health shocks and retirement: the role of welfare state institutions. European Journal of Aging, 4(3), pp. 183-190. doi: 10.1007/s10433-007-0062-4

6. De Jong, P., Lindeboom, M. and Van der Klaauw, B., 2011. Screening disability insurance applications. Journal of the European Economic Association, 9(1), pp. 106-129. doi: 10.1111/j.1542-4774.2010.01002.x

7. DZS, 2011. Popis stanovništva, kućanstava i stanova 2011. godine [online]. Available at: <http://www.dzs.hr/Hrv/censuses/census2011/results/censustabshtm.htm>.

8. DZS, 2016. Socijalna zaštita u Republici Hrvatskoj u 2014. Priopćenje, 27 May 2016, Zagreb: Državni ured za statistiku.

9. Eurostat, 2016a. Social protection [online]. Available at: $<\mathrm{http}: / /$ ec.europa.eu/ eurostat/web/social-protection/data/database>.

10. Eurostat, 2016b. Health status and determinants [online]. Available at: $<$ http:// ec.europa.eu/eurostat/web/health/health-status-determinants/data/database>.

11. Eurostat, 2016c. Health and safety at work [online]. Available at: <http:// ec.europa.eu/eurostat/web/health/health-safety-work>.

12. Falkstedt, D. [et al.], 2016. Do working conditions explain the increased risks of disability pension among men and women with low education? A follow-up of Swedish cohorts. Scandinavian Journal of Work, Environment and Health, 40(5), pp. 483-492. doi: 10.5271/sjweh.3441

13. Gjesdal, S. [et al.], 2004. Predictors of disability pension in long-term sickness absence: results from a population-based and prospective study in Norway 1994-1999. European Journal of Public Health, 14(4), pp. 398-405. doi: 10.1093/eurpub/14.4.398

14. Gravseth, H. M. [et al.], 2007. Life course determinants for early disability pension: a follow-up of Norwegian men and women born 1967-1976. European Journal of Epidemiology, 22(8), pp. 533-543. doi: 10.1007/s10654-007-9139-9

15. Hall, R. C. W. and Hall, R. C. W., 2006. Malingering of PTSD: forensic and diagnostic considerations, characteristics of malingerers and clinical presentations. General Hospital Psychiatry, 28(6), pp. 525-535. doi: 10.1016/j.genhosppsych.2006.08.011 
16. Hanel, B., 2012. The effect of disability pension incentives on early retirement decisions. Labour Economics, 19(4), pp. 595-607. doi: 10.1016/j.labeco.2012. 05.011

17. HNB, 2016. Glavni makroekonomski indikatori [online]. Available at: $<$ http:// www.hnb.hr/statistika/glavni-makroekonomski-indikatori>.

18. HZJZ, 2016a. Hrvatski zdravstveno-statistički ljetopis za 2015. godinu. Zagreb: Hrvatski zavod za javno zdravstvo.

19. HZJZ, 2016b. Izvješće o osobama s invaliditetom u Republici Hrvatskoj. Zagreb: Hrvatski zavod za javno zdravstvo.

20. HZMO, 2015. Statističke informacije. Zagreb: Hrvatski zavod za mirovinsko osiguranje.

21. HZMO, 2016a. Izvješće o radu i poslovanju Hrvatskog zavoda za mirovinsko osiguranje za 2015. Zagreb: Hrvatski zavod za mirovinsko osiguranje.

22. HZMO, 2016b. Statističke informacije. Zagreb: Hrvatski zavod za mirovinsko osiguranje.

23. Karlsson, N. E. [et al.], 2008. Risk factors for disability pension in a population-based cohort of men and women on long-term sick leave in Sweden. European Journal of Public Health, 18(3), pp. 224-231. doi: 10.1093/eurpub/ ckm128

24. Krokstad, S. [et al.], 2004. The importance of social characteristics of communities for the medically based disability pension. European Journal of Public Health, 14(4), pp. 406-412. doi: 10.1093/eurpub/14.4.406

25. Krokstad, S. and Westin, S. 2004. Disability in society - medical and nonmedical determinants for disability pension in a Norwegian total country population study. Social Science and Medicine, 58(10), pp. 1837-1848. doi: 10.1016/S0277-9536(03)00409-X

26. Legatum Institute, 2015. 2015 Legatum Prosperity Index [online]. Available at: $<$ http://www.li.com/activities/publications/2015-legatum-prosperity-index $>$.

27. Marušić, Lj., 2011. Institut invalidnosti u mirovinskom osiguranju [online]. Available at: <http://www.ijf.hr/upload/files/file/AMS/zbornik.pdf>.

28. McNally, R.J. and Frueh, B.C., 2013. Why are Iraq and Afghanistan War veterans seeking PTSD disability compensation at unprecedented rates?. Journal of Anxiety Disorders, 27(5), pp. 520-526. doi: 10.1016/j.janxdis.2013.07.002

29. MSPM, 2014. Nacionalno socijalno izvješće 2014. Zagreb: Ministarstvo socijalne politike i mladih.

30. MSPM, 2015. Strategija za suzbijanje pogrešaka, zlouporabe i korupcije na području socijalne zaštite u Republici Hrvatskoj za razdoblje od 2015. do 2020. godine. Zagreb: Ministarstvo socijalne politike i mladih.

31. North, D. C., 1994. Economic Performance Through Time. The American Economic Review, 84(3), pp. 359-368.

32. OECD, 2003. Transforming Disability into Ability. Paris: OECD.

33. Österberg, T. and Gustafsson, B., 2006. Disability pension among immigrants in Sweden. Social Science and Medicine, 63(3), pp. 805-816. doi: 10.1016/ j.socscimed.2006.02.009 
34. Rismondo, M., 2000. Definicija invalidnosti i njezin razvoj u hrvatskom mirovinskom osiguranju. Revija za socijalnu politiku, 7(3), pp. 299-309. doi: 10.3935/rsp.v7i3.243

35. Robroek, S. J. [et al.], 2013. Poor health, unhealthy behaviors, and unfavorable work characteristics influence pathways of exit from paid employment among older workers in Europe: a four year follow-up study. Scandinavian Journal of Work, Environment and Health, 39(2), pp. 125-133. doi: 10.5271/sjweh.3319

36. Staubli, S., 2011. The impact of stricter criteria for disability insurance on labor force participation. Journal of Public Economics, 95(9-10), pp. 12231235. doi: 10.1016/j.jpubeco.2011.05.008

37. Transparency International, 2015. Corruption Perceptions Index 2015 [online]. Available at: <http://www.transparency.org/cpi2015>.

38. Upmark, M. [et al.], 2001. Conditions during childhood and adolescence as explanations of social class differences in disability pension among young men. Scandinavian Journal of Public Health, 29(2), pp. 96-103. doi: 10.1177/ 14034948010290020601

39. USKOK, 2008. Priopćenja. Zagreb: Ured za suzbijanje korupcije i organiziranog kriminaliteta.

40. Vlada RH, 2014. Izvješće o provedbi Zakona o pravima hrvatskih branitelja iz Domovinskog rata i članova njihovih obitelji za 2013. godinu. Zagreb: Vlada Republike Hrvatske.

41. Vukorepa, I., 2015. Lost between Sustainability and Adequacy: Critical Analysis of the Croatian Pension System's Parametric Reform. Revija za socijalnu politiku, 22(3), pp. 279-308. doi: 10.3935/rsp.v22i3.1307

42. WHO, 2016. European Health for All Database (HFA-DB) [online]. Available at: <http://data.euro.who.int/hfadb/>.

43. Zakon o mirovinskom osiguranju, NN 02/98, 127/00, 109/01, 147/02, 117/03, 30/04, 177/04, 92/05, 43/07, 79/07, 35/08, 40/10, 121/10, 157/13, 151/14, 33/15, 93/15. Zagreb: Narodne novine.

44. Zakon o pravima hrvatskih branitelja iz Domovinskog rata i članova njihovih obitelji, NN 174/04, 92/05, 02/07, 107/07, 65/09, 137/09, 146/10, 55/11, 140/12, 19/13, 33/13, 148/13, 92/14. Zagreb: Narodne novine.

45. Žilić, I., 2015. Effect of forced displacement on health. EIZ Working Papers, No. EIZ-WP-1503. 